\title{
PCR-based sensitive detection of the edible fungus Boletus edulis from rDNA ITS sequences
}

\author{
Bin Lian* \\ State Key Laboratory of Environmental Geochemistry \\ Institute of Geochemistry \\ Chinese Academy of Sciences \\ Guiyang, China \\ Tel: 868515895148 \\ Fax: 868515895148 \\ E-mail: bin2368@vip.163.com \\ Jin-ping Zang \\ Jiangsu Key laboratory for Biodiversity and Biotechnology \\ College of Life Sciences \\ Nanjing Normal University \\ Nanjing, China \\ Tel: 862585891067 \\ Fax: 862585891050 \\ E-mail: zangjp@sina.com \\ Wei-guo Hou \\ State Key Laboratory of Environmental Geochemistry \\ Institute of Geochemistry \\ Chinese Academy of Sciences \\ Guiyang, China \\ Tel: 868515895148 \\ Fax: 868515895148 \\ E-mail: haital@126.com

\section{Sheng Yuan} \\ Jiangsu Key laboratory for Biodiversity and Biotechnology \\ College of Life Sciences \\ Nanjing Normal University \\ Nanjing, China \\ Tel: 862585891067 \\ Fax: 862585891050 \\ E-mail: shengyuan@email.njnu.edu.cn \\ Donald L. Smith \\ Department of Plant Science \\ McGill University \\ Macdonald Campus \\ Quebec, Canada \\ Tel: 15143987866 \\ Fax: 15143987897 \\ E-mail: Donald.Smith@McGill.Ca
}

Financial support:The National Science Fund for Innovative Research Group (No. 40721002); Attracting Talents of Nanjing Normal University (No. 184070H2B39); Ministry of Science and Technology of China (No. 2006CB403200).

Keywords: Boletus edulis, detection, edible fungi, internal transcribed spacer, PCR, specific primers.

Abbreviations: AR-PCR: arbitrary primed PCR

ITS: internal transcribed spacer

NJ: neighbour-joining

PCR: polymerase chain reaction

RAPD: random amplified polymorphic DNA

RFLP: restriction fragment length polymorphism

Identification of commercially important fungi, such as

the valuable edible fungus Boletus edulis can be difficult

*Corresponding author 
considering visual or metabolic approaches. Based on phylogenetic analysis of the rDNA ITS sequence, a pair of specific primers was designed for differentiating $B$. edulis from other mushrooms by PCR. PCR was performed with total DNA as a template at an annealing temperature between $56-60^{\circ} \mathrm{C}$. Positive amplicons were obtained from $B$. edulis with all DNA templates from fruit bodies and cultured mycelium, but not from other fungal species at an annealing temperature of $60^{\circ} \mathrm{C}$. The result indicated that $B$. edulis could be clearly distinguished from other fungi by PCR, and there were no misidentifications under the reaction conditions used. The primers were also successfully employed to identify various tissues of $B$. edulis.

Boletus edulis is a valuable edible mushroom, and also a medicinal fungus that has long been used as a Chinese traditional medicine in the treatment of various gastric digestive diseases. Because of its delicious taste, rich nutrient value, anti-tumour, immunomodulatory and lipidlowering effects, as well as other possible medical values (Manzi et al. 2001), B. edulis has attracted much attention, resulting in an increasing number of studies on its physiological, biochemical and pharmacological properties all over the world (Tang and Lu, 1999; Manzi et al. 2001; Davoli and Weber, 2002; Wilburn et al. 2004; Wang and Lu, 2005; Tsai et al. 2007). In addition, ectomycorrhizal fungi, including $B$. edulis, play an important role by not only promoting the growth of the plants, but also mobilizing mineral nutrients from rhizosphere soils (van Hees et al. 2004; Kahle et al. 2005; Fomina et al. 2006; Wilson et al. 2007). Accurate taxonomic identification and phylogenetic classification of $B$. edulis would be helpful in characterizing the novel genes and useful metabolites that could be provided by this fungus, and could help in delivering useful information for future genetic engineering or the cultivation and commercialization of this important species (Moor et al. 2002; Iotti et al. 2005; Agueda et al. 2006; Mello et al. 2006). On the other hand, the evolutionary history and relationships of $B$. edulis with other basidiomycetes remains controversial in spite of its economic importance (Hibbett and Donoghue, 2001; Leonardi et al. 2005; Peintner et al. 2007). To solve such problems, correct identification of precious fungi is necessary. Unfortunately, traditional methods for identifying mushrooms are not reliable and are also problematic because most fungi in the mycelial phase are difficult to distinguish from each other using either morphological characteristics or organic/inorganic components. Therefore, an advanced method needs to be developed for the identification of $B$. edulis and other mushroom.

With current advances in biotechnology, molecular genetic markers have been employed for rapid identification of different kinds of mushrooms (Lee et al. 2006; Moreau et al. 2006; Froslev et al. 2007; Urbanelli et al. 2007). The development of DNA-based PCR and taxon specific primers (Mullis and Faloona, 1987) has made the detection

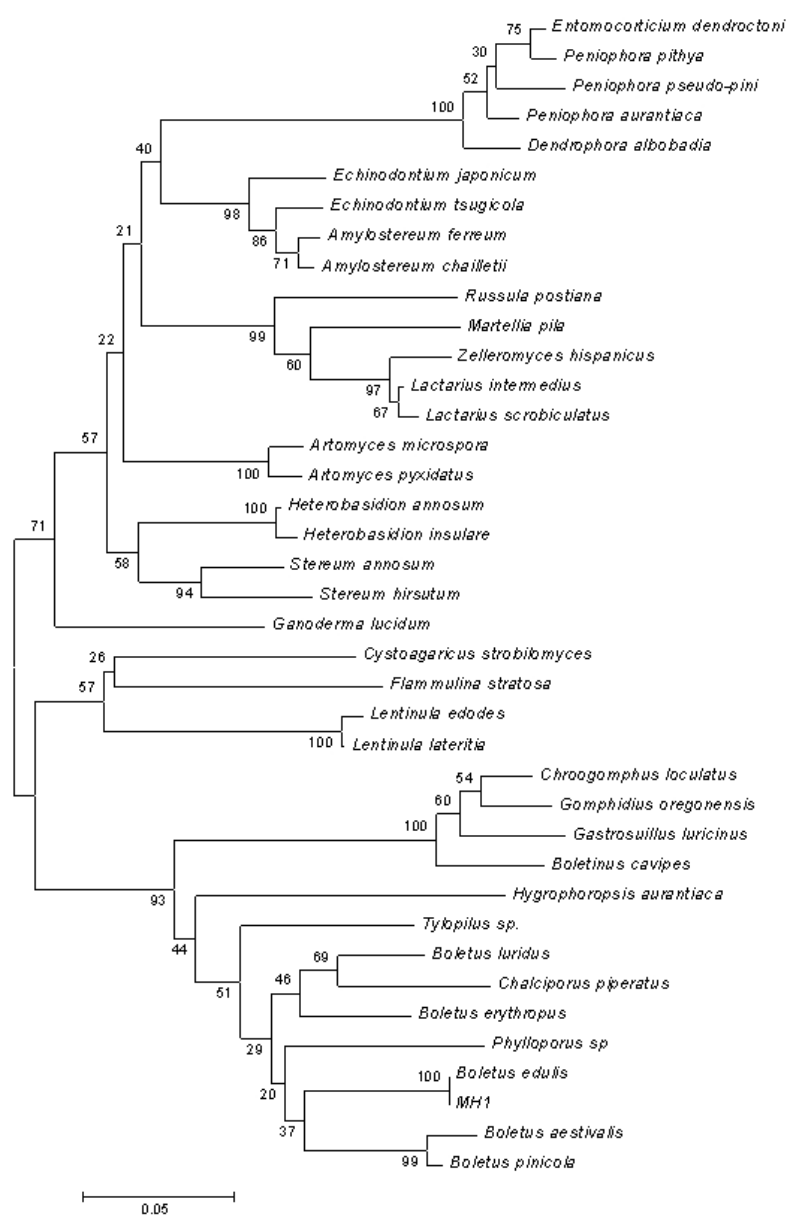

Figure. 1. Phylogenetic relationships of Homobasidiomycetes inferred from ITS Sequences of $\mathbf{4 0}$ equally parsimonious trees. The numbers represent bootstrap frequencies. Branches within a vertical line represent the same family.

and study of fungi increasingly feasible. The internal transcribed spacer (ITS) region has generally been considered a convenient target for the molecular identification of fungi at species level (Sanchez-Ballesteros et al. 2000). Henry et al. (2000) identified the fungus Aspergillus at species level and differentiated it from other true pathogenic and opportunistic molds using ITS 1 and ITS 2, allowing for earlier diagnosis and screening of effective antifungal agents for patients. Oh et al. (2003) developed an effective detection method for wood-decaying fungi by hybridization of immobilized sequence-specific oligonucleotide probes with fluorescent-labeled PCRamplified fungal rDNA ITS sequences. In this study, a preliminary phylogenetic analysis of ITS sequences was performed, and the results were used to assess the phylogenetic relationship between Boletus and other species. Furthermore, a set of PCR primers specific for $B$. edulis was designed for establishing a convenient and accurate method of identifying this edible mushroom. 
Table 1. Species used for identification assay.

\begin{tabular}{|c|c|c|c|}
\hline $\mathbf{N}^{\circ}$ & Strain & Source & Identification material \\
\hline 1 & B. edulis (MH1) & Yunnan & Fruiting body \\
\hline 2 & B. edulis & Isolated from Yunnan & Liquid shaken mycelia \\
\hline 3 & Volvariella volvacea & Jiangsu & Liquid shaken mycelia \\
\hline 4 & Ganoderma lucidum & Jiangsu & Liquid shaken mycelia \\
\hline 5 & Ganoderma sinense & Jiangsu & Liquid shaken mycelia \\
\hline 6 & Aspergillus oryzae & Jiangsu & Liquid shaken mycelia \\
\hline 7 & Aspergillus nidulans & Jiangsu & Liquid shaken mycelia \\
\hline
\end{tabular}

\section{MATERIALS AND METHODS}

\section{Sample sources}

B. edulis fruit bodies (MH1) were collected from Kunming, Yunnan Province, China and were identified according to a previously published guide (Wei, 1979). A small tissue from the fresh section between the pileus and stipe was cut with a sterilized knife and placed into a slant of GlucosePeptone-Agar medium (Glucose $20 \mathrm{~g}$, peptone $2 \mathrm{~g}, \mathrm{~K}_{2} \mathrm{HPO}_{4}$ $1 \mathrm{~g}, \mathrm{KH}_{2} \mathrm{PO}_{4} 0.5 \mathrm{~g}, \mathrm{MgSO}_{4} 0.5 \mathrm{~g}, \mathrm{~V}_{\mathrm{B} 1} 0.05 \mathrm{mg}$, Agar $18 \mathrm{~g}$, and $\mathrm{H}_{2} \mathrm{O} 1000 \mathrm{~mL}$ ). The tissue was incubated for 8 weeks at $26^{\circ} \mathrm{C}$, until pure mycelium covered the agar surface in the slant tube. Table 1 lists 7 samples of 6 species used in this study. The specimens were placed in the collection of Nanjing Normal University, China. The B. edulis isolate and other fungal species were fostered in $100 \mathrm{~mL}$ sterilized liquid Glucose-Peptone-Agar (agar free) medium, $26^{\circ} \mathrm{C}$ and $150 \mathrm{rpm}$. Visualized spherical mycelia of B. edulis can be obtained about 7 weeks later, and those of other species, which are growing much faster, can be obtained within a week.

\section{DNA extraction}

Total genomic DNA was extracted as described by Graham et al. (1994). About $100 \mathrm{mg}$ fresh mushroom tissue or fungal mycelia (Table 1) were ground in $0.8 \mathrm{~mL}$ lysis buffer (200 mM Tris-HCl, pH 8.0, $100 \mathrm{mM} \mathrm{NaCl,} 25 \mathrm{mM}$ EDTA, and $0.5 \%$ Sodium dodecyl sulfate) and transferred into a $1.5 \mathrm{~mL}$ microfuge tube. After incubation at $65^{\circ} \mathrm{C}$ for $1 \mathrm{hr}, 0.7 \mathrm{~mL} 5 \%$ CTAB buffer (5\% CTAB [w/v], $100 \mathrm{mM}$ Tris-HCl pH 8.0, 1.4 M NaCl) was added, and the mixture was placed in a water bath at $65^{\circ} \mathrm{C}$ for $10 \mathrm{~min}$. The solution was extracted with an equal volume of a mixture of phenol:chloroform:isoamyl alcohol (25:24:1, v/v), and then centrifuged at $12,000 \mathrm{rpm}$ for $10 \mathrm{~min}$, followed by extraction with chloroform: isoamyl alcohol (24:1, v/v) until the upper phase was clear. The upper phase was then transferred to a new tube and DNA was precipitated with an equal volume of isopropanol. The precipitate was washed with $70 \%$ ethanol and pure ethanol, dried, and re-suspended in $50 \mu \mathrm{L}$ sterile water. Genomic DNA was visualized in a Gel Documentation System LG 2020 (Hangzhou Langqi, Inco., China).

\section{PCR amplification and sequencing of the rDNA ITS region}

Amplification and sequencing of $B$. edulis was performed using a pair of universal primers: ITS5 (5' GGAAGTAAAAGTCGTAACAAGG 3') and ITS4 (5' TCCTCCGCTTA TTGATATGC 3') (White et al. 1990) for the region containing ITS1 and ITS2 and the 5.8S rDNA, and they were also employed as a positive control in subsequent diagnostic PCR. The amplification was carried out in a PTC-100 thermocycler in a $50 \mu \mathrm{L}$ reaction mixture containing $5 \mu \mathrm{L} 10$ x PCR buffer, $4 \mu \mathrm{L} 25 \mathrm{mM} \mathrm{MgCl}_{2}, 1$ $\mu \mathrm{L}$ dNTP Mix (10 mM each), $1 \mu \mathrm{L} 20 \mu \mathrm{M}$ each primer, 4 $\mu \mathrm{L}$ template DNA, and $0.25 \mu \mathrm{L}$ Taq DNA polymerase $(5 \mathrm{U} / \mu \mathrm{L})$. The reaction mixtures were denatured at $94^{\circ} \mathrm{C}$ for $5 \mathrm{~min}$ and subjected to 30 cycles of $1 \mathrm{~min}$ at $94^{\circ} \mathrm{C}, 1 \mathrm{~min}$ at $56-60^{\circ} \mathrm{C}, 1 \mathrm{~min}$ at $72^{\circ} \mathrm{C}$, and a final extension step of 10 min at $72^{\circ} \mathrm{C}$. Amplified products were purified using a DNA purification kit (Shanghai Watson Bioengineering, Inc., China) according to the manufacturer's instructions, and then sequenced directly with BigDyeTM on an ABIPRISM 310 automated DNA sequencer (PE Applied Biosystems Inco., USA).

\section{Phylogenetic analysis}

Sequence data from ribosomal ITS genes of Homobasidiomyetes were used to perform a preliminary phylogenetic analysis. 40 ITS sequences were obtained from Genbank-database (htpp://www.ncbi.nlm.nih.gov/) (Table 2). These species designations were based on 

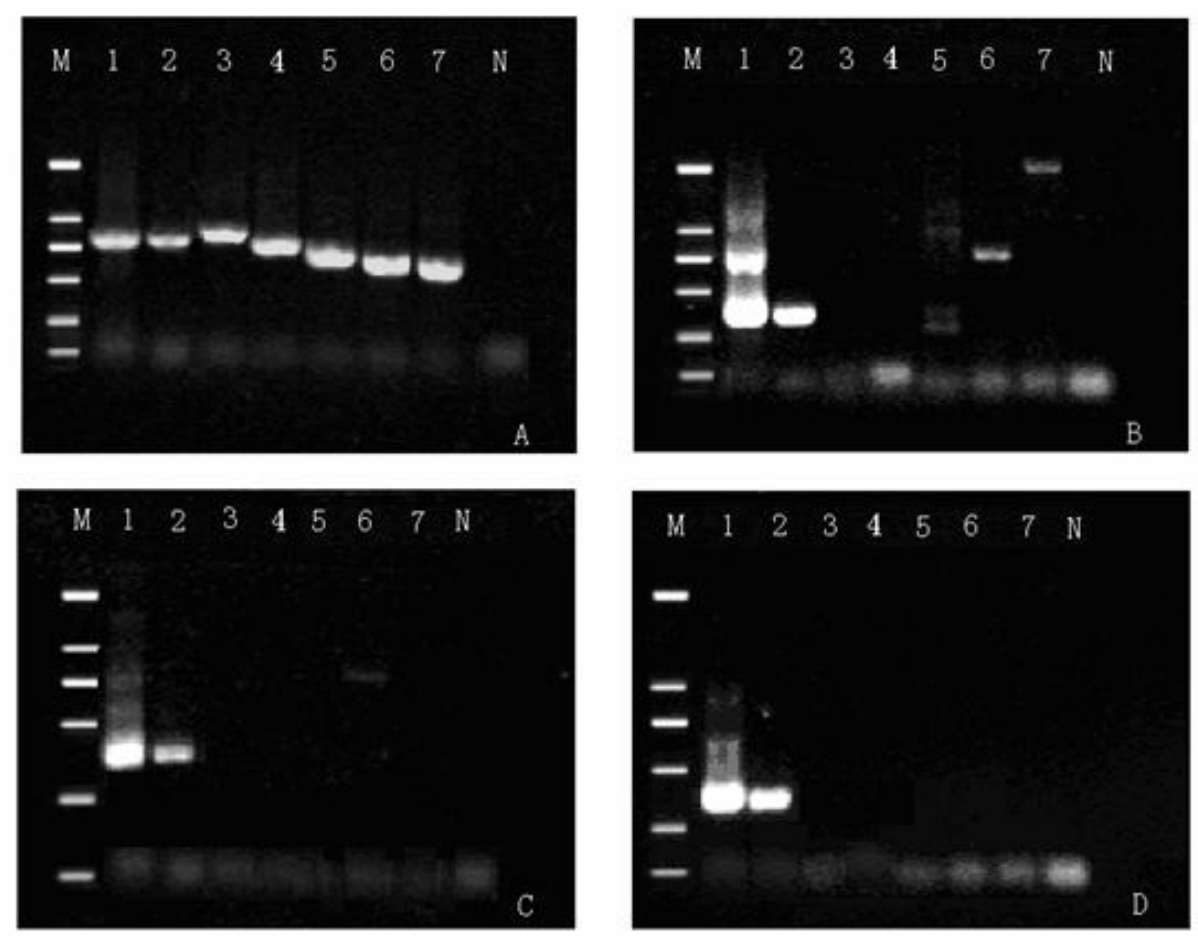

Figure 2. PCR amplification of ITS gene region at different annealing temperatures.

(a) Positive control annealing at $56^{\circ} \mathrm{C}$ with the primers ITS4 and ITS5.

(b), (c), (d) Annealing at $56^{\circ} \mathrm{C}, 58^{\circ} \mathrm{C}$ and $60^{\circ} \mathrm{C}$ respectively with the primers $\mathrm{BE}-1$ and $\mathrm{BE}-2$.

M: DNA marker (DL-2000); N: Negative control without DNA template. The numeric codes are concordant with those in Table 1.

morphological species concepts or referred to previous reports (Hibbett et al. 1997; Hibbett and Binder, 2002). Phylogenetic analysis of the aligned sequences was performed by Neighbor-Joining (NJ) analysis, using the MEGA (2.0) Kimura2-Parameter Distance model, in which gaps were treated as missing data (Jeanmougin et al. 1998). Bootstrapping was performed with NJ analysis using 1000 replicates.

\section{Primer design}

Based on the results of the phylogenetic analyses, we investigated ITS sequences of the Boleteae family and of other species (Table 3). A pair of primers, BE1 and BE2, was designed for PCR detection of authentic species of $B$. edulis. The closely related rDNA ITS sequences were retrieved from the DNA database using the BLAST program (htpp://www.ncbi.nlm.nih.gov/blast/) to verify the specificity of the primer pairs. The primer pairs were tested for sensitivity with total genomic DNA from 7 samples of fungi (Table 1) in PCR and a DNA fragment (approximately $300 \mathrm{bp}$ ) from the rDNA ITS gene was amplified. Diagnostic PCR was performed under the conditions mentioned above.

\section{RESULTS}

\section{Sequencing and phylogenetic analysis}

A 698 bp fragment of the r-DNA ITS region was amplified and sequenced, the results were submitted to gene bank databases (Accession number: DQ352861).

The phylogenetic tree was generated from 40 aligned sequences (Table 2) of Homobasidiomycetes (Figure 1). The genus of Boletus lineage could be identified from the tree, in spite of a low frequency value and other species such as Phylloporus sp. and Chalciporus piperatus appearing within the Boletus lineage (indicated in the bottom of the tree). We comprehend the situation for that the Boletus, Phylloporus and Chalciporus genera all belong to the family Boletaceae and maybe share a very close phylogenetic distance. However, it is also shown that there are great genetic variations within the Boletus genus according to phylogenetic distances based on ITS sequences, and it was feasible to design a pair of specific primers within $B$. edulis ITS sequence to identify the fungal species. 
Table 2. Species of Homobasidiomyetes used for phylogenetic analysis of Boletus.

\begin{tabular}{|c|c|c|c|}
\hline Serial number & Length (bp) & Strain name & Accession number \\
\hline 1 & 783 & Boletus edulis & EF646278 \\
\hline 2 & 698 & $\mathrm{MH} 1$ & DQ352861 \\
\hline 3 & 622 & Boletinus cavipes & A.J419205 \\
\hline 4 & 657 & Chroogomphus loculatus & AF205668 \\
\hline 5 & 659 & Cystoagaricus strobilomyces & AY176347 \\
\hline 6 & 671 & Gomphidius oregonensis & L54114 \\
\hline 7 & 627 & Hygrophoropsis aurantiaca & $\mathrm{A}_{\mathrm{N}} \mathbf{4 1 9 2 0 2}$ \\
\hline 8 & 650 & Phylloporus sp. & AY456356 \\
\hline 9 & 783 & Tylopilus sp. & AY456372 \\
\hline 10 & 677 & Xerocomus chrysenteron & $\mathrm{XCH} 419223$ \\
\hline 11 & 957 & Boletus aestivalis & AY130295 \\
\hline 12 & 684 & Boletus luridus & AY278765 \\
\hline 13 & 602 & Boletus enythropus & $\mathrm{A}_{\mathrm{J}} / 496595$ \\
\hline 14 & 642 & Boletus pinicola & A, 419190 \\
\hline 15 & 632 & Chalciporus piperatus & A, 419193 \\
\hline 16 & 661 & Gastrosuilus luricinus & M91612 \\
\hline 17 & 532 & Echinadontium tsugicola & AF218398 \\
\hline 18 & 534 & Echinadontium japonicum & AF218399 \\
\hline 19 & 547 & Heterobasidion annosum & AF289929 \\
\hline 20 & 564 & Heterobasidion insulare & AF289932 \\
\hline 21 & 665 & Clavicorona microspora & AF336137 \\
\hline 22 & 640 & Clavicorona pyxidata & AF336139 \\
\hline 23 & 549 & Stereum annosum & AF218401 \\
\hline 24 & 568 & Stereum hirsutum & AF218400 \\
\hline 25 & 547 & Entonocorticium dendroctoni & AF119506 \\
\hline 26 & 546 & Peniophora pithya & AF119520 \\
\hline 27 & 547 & Peniophora pseudopini & AF119514 \\
\hline 28 & 551 & Dendrophora albobadia & AF119522 \\
\hline 29 & 600 & Ganoderma iucidum & AF079584 \\
\hline 30 & 684 & Peniophora aurantiaca & AF210819 \\
\hline 31 & 675 & Lactarius intermedius & AF140257 \\
\hline 32 & 736 & Lactarius scrobiculatus & AF140262 \\
\hline 33 & 518 & Amylostereum ferreum & AF218390 \\
\hline 34 & 518 & Amylostereum chailletii & AF218391 \\
\hline 35 & 620 & Martellia pila & AF230893 \\
\hline 36 & 626 & Russula postiana & AF230898 \\
\hline 37 & 638 & Zelleromyces hispanicus & AF231911 \\
\hline 38 & 803 & Flammulina stratosa & AFO47872 \\
\hline 39 & 707 & Lentinula edodes & AF079572 \\
\hline 40 & 728 & Lentinula lateritia & AF079573 \\
\hline
\end{tabular}

\section{Species specific PCR primers design}

The primers were designed on the basis of phylogenetic analysis, and then six fungal species were chosen to test them. The selected ITS amplicon for specific primers ranged from bp $4 \sim 26$, and from bp $334 \sim 354$, respectively. The sequences of the specific primer pairs were BE1 (5' CATTATCGAGTTAGACCGGGAAG 3') and BE2 (5' CCATGCCCTCGAGATCAGA TC 3').

The primer-blast results showed that partial sequences of the ITS of the isolates $B$. edulis (from China and Switzerland), and B. aereus and B. aestivalis (from Italy) shared $100 \%$ identity with the primer BE1; only the sequence of B. edulis from Yunnan, China shared 100\% identity with the primer BE2 and an isolate of $B$. aestivalis from Italy shared 95\% (20/21) identity with BE2. However, the false results may be eliminated by a higher annealing temperature during diagnostic PCR.

All the samples gave amplicons with sizes between $600 \mathrm{bp}$ and $700 \mathrm{bp}$ with the primer pairs of ITS5 and ITS4 (Figure 2a). With the specific primers BE1 and BE2 and a chosen annealing temperature of $56^{\circ} \mathrm{C}$, a DNA fragment with a size of about 300 bp was clearly amplified from total DNA from the $B$. edulis isolate as well as from tissues of $B$. edulis fruiting body, but a weak signal was obtained in the case of G. sinense, A. oryzae and A. nidulans (Figure 2b). When 
Table 3. Species of $B$. edulisand some other fungi used for primer design.

\begin{tabular}{|c|c|c|c|}
\hline $\mathbf{N}^{\circ}$ & Classification & Length (bp) & Accession number \\
\hline 1 & Boletus edulis & 759 & AY278769 \\
\hline 2 & Agaricus campestris & 566 & AJ133389 \\
\hline 3 & Flammulina velutipes & 802 & AB064957 \\
\hline 4 & Pleurotus ostreatus & 537 & AF423120 \\
\hline 5 & Volvariella volvacea & 728 & U15973 \\
\hline 6 & Ganoderma lucidum & 600 & AF079584 \\
\hline 7 & Clavicorona pyxidata & 640 & AF336139 \\
\hline 8 & Heterobasidion annosum & 547 & AF289929 \\
\hline 9 & Echinadontium tsugicola & 532 & AF218398 \\
\hline 10 & Boletus satanas & 844 & DQ534567 \\
\hline 11 & Boletus pallidus & 754 & DQ534564 \\
\hline 12 & Boletus caespitosus & 879 & DQ534638 \\
\hline 13 & Boletus dryophilus & 843 & AY185183 \\
\hline
\end{tabular}

the annealing temperature was increased to $58^{\circ} \mathrm{C}$, we were able to eliminate the negative signals of $G$. sinsense and $A$. nidulans other than $A$. oryzae (Figure 2c). Once the annealing temperature was set to $60^{\circ} \mathrm{C}$, the amplified DNA band only appeared for $B$. edulis, and no PCR product was obtained for other fungi (Figure 2d).

\section{DISCUSSION}

With increasing demand for edible and medicinal fungal materials, the shortage of Chinese edible and medicinal wild fungi, such as B. edulis, G. lucidum, Tricboloma mutsutake and Cordyceps sinensis, becomes more severe. Consequently, adulterants or substitutes for those precious fungi begin to appear in the market of some areas, being sold fraudulently for high profit. Identification of those high-quality fungal species is not only necessary but has great economic significance as it will allow product distributors to verify the material they are selling.

Molecular technology can greatly enhance detection sensitivity, as well as simplify and expedite the identification of fungi. Several methods, including random amplified polymorphic DNA (RAPD), arbitrary primed PCR (AR-PCR), restriction fragment length polymorphism (RFLP), PCR-RFLP and DNA sequencing, have recently been used for the authentication of biological materials
(Lotufo et al. 1994; Lakra et al. 2007; Taylor and Ford, 2007). Although they have been proven to be efficient in taxonomic identification and in distinguishing genuine crude drugs from their substitutes or adulterants in previous reports, the application of these methods is limited by the high cost of the fine quality template DNA that is required in these experiments. The reproducibility of RAPD analysis is heavily affected by the quality and concentration of the template DNA, the ratio of template to primer, and slight fluctuations of reacting components or cycling parameters. In regards to the PCR-RFLP method, the length of PCR products also confines its utilization, as the number of restriction enzyme sites is limited in DNA segments between two primers. Although sequence analysis of PCR products is quite precise and stable, the relatively high expense of DNA sequencing and the sensitivity of contamination in the PCR reaction using universal primers obstructs its wide acceptance in quality control of medicinal materials (Wang et al. 2000).

This study presents an efficient method for identifying economically important fungi on species level. Based on the target DNA sequence analysis of those high-value species of medicinal mushrooms, we designed a pair of specific primers that exactly match a specific DNA sequence of $B$. edulis, and incompletely match with the sequence of other species. Therefore, a high-stringency 
PCR reaction with primers specific for $B$. edulis gave a positive signal only for genuine species of $B$. edulis, but not for other fungi. Furthermore, the process of identification by PCR is very simple and convenient to use.

We choose $B$. edulis for the design of detection PCR primers because it is abundant in China. To probe into the evolutionary history of the genus Boletus and its relationship with other basidiomycetes, and to prepare for the specific primer design, we established a phylogenetic tree for Boletus and some strains related at the order and family levels in the Homobasidiomycetes. Based on this phylogenetic tree, the ITS sequences from Boleteae family and other species were aligned, and the results were used to design a pair of specific primers (BE-1 and BE-2) only for Boletus edulis.

In conclusion, an accurate and practical phylogenetic analysis establishes a theoretical foundation for defining a classified status of new edible or medicinal fungi. In addition, their evolutionary relationships could provide an important clue for further exploration of the active compounds. Furthermore, specific detection PCR is a timeand cost-effective method for the authentication of edible and medicinal mushrooms. This method will aid in the quality control of identification of other economical materials and species, especially in the inspection of Chinese B. edulis export in big batch.

\section{REFERENCES}

AGUEDA, B.; PARLADE, J.; DE MIGUEL, A.M. and MARTINEZ-PENA, F. Characterization and identification of field ectomycorrhizae of Boletus edulis and Cistus ladanifer. Mycologia, January-February 2006, vol. 98, no. 1, p. 23-30.

DAVOLI, P. and WEBER, R.W.S. Simple method for reversed-phase high-performance liquid chromatographic analysis of fungal pigments in fruit-bodies of Boletales (Fungi). Journal of Chromatography A, July 26 2002, vol. 964, no. 1-2, p. 129-135.

FOMINA, M.; CHARNOCK, J.M.; HILLIER, S.; ALEXANDER, I.J. and GADD, G.M. Zinc phosphate transformations by the Paxillus involutus/pine ectomycorrhizal association. Microbial Ecology, August 2006, vol. 52, no. 2, p. 322-333.

FROSLEV, T.G.; JEPPESEN, T.S.; LAESSOE, T. and KJOLLER, R. Molecular phylogenetics and delimitation of species in Cortinarius section Calochroi (Basidiomycota, Agaricales) in Europe. Molecular Phylogenetics and Evolution, July 2007, vol. 44, no. 1, p. 217-227.

GRAHAM, G.C.; MAYER, P. and HENRY, R.J. A simplified method for the preparation of fungal genomic DNA for PCR and RAPD analysis. Biotechniques, January 1994, vol. 16, no. 1, p. 48-50.
HENRY, T.; IWEN, P.C. and HINRICHS, S.H. Identification of Aspergillus species using internal transcribed spacer regions 1 and 2. Journal of Clinical Microbiology, April 2000, vol. 38, no. 4, p. 1510-1515.

HIBBETT, D.S. and DONOGHUE, M.J. Analysis of character correlations among wood decay mechanisms, mating systems, and substrate ranges in homobasidiomycetes. Systematic Biology, March-April 2001, vol. 50, no. 2, p. 215-242.

HIBBETT, D.S. and BINDER, M. Evolution of complex fruiting-body morphologies in homobasidiomycetes. Proceedings of the Royal Society of London Series BBiological Sciences, October 2002, vol. 269, no. 1504, p. 1963-1969.

HIBBETT, D.S.; PINE, E.M.; LANGER, E.; LANGER, G. and DONOGHUE, M.J. Evolution of gilled mushrooms and puffballs inferred from ribosomal DNA sequences. Proceedings of the National Academy of Sciences of the United States of America, October 1997, vol. 94, no. 22, p. 12002-12006.

IOTTI, M.; BARBIERI, E.; STOCCHI, V. and ZAMBONELLI, A. Morphological and molecular characterisation of mycelia of ectomycorrhizal fungi in pure culture. Fungal Diversity, June 2005, vol. 19, p. 51-68.

KAHLE, P.; BAUM, C. and BOELCKE, B. Effect of afforestation on soil properties and mycorrhizal formation. Pedosphere, December 2005, vol. 15, no. 6, p. 754-760.

JEANMOUGIN, F.; THOMPSON, J.D.; GOUY, M.; HIGGINS, D.G. and GIBSON, T.J. Multiple sequence alignment with Clustal x. Trends in Biochemical Sciences, October 1998, vol. 23, no. 10, p. 403-405.

LAKRA, W.S.; GOSWAMI, M.; MOHINDRA, V.; LAL, K.K. and PUNIA, P. Molecular identification of five Indian sciaenids (pisces: perciformes, sciaenidae) using RAPD markers. Hydrobiologia, June 2007, vol. 583, p. 359-363.

LEE, J.S.; LIM, M.O.; CHO, K.Y.; CHO, J.H.; CHANG, S.Y. and NAM, D.H. Identification of medicinal mushroom species based on nuclear large subunit rDNA sequences. Journal of Microbiology, February 2006, vol. 44, no. 1, p. 29-34.

LEONARDI, M.; PAOLOCCI, F.; RUBINI, A.; SIMONINI, G. and PACIONI, G. Assessment of inter- and intra-specific variability in the main species of Boletus edulis complex by ITS analysis. FEMS Microbiology Letters, February 2005, vol. 243, no. 2, p. 411-416.

LOTUFO, R.F.M.; FLYNN, J.; CHEN, C. and SLOTS, J. Molecular-detection of bacteroides-forsythus in human periodontitis. Oral Microbiology and Immunology, June 1994, vol. 9, no. 3, p. 154-160. 
MANZI, P.; AGUZZI, A. and PIZZOFERRATO, L. Nutritional value of mushrooms widely consumed in Italy. Food Chemistry, May 2001, vol. 73, no. 3, p. 321-325.

MELLO, A.; GHIGNONE, S.; VIZZINI, A.; SECHI, C.; RUIU, P. and BONFANTE, P. ITS primers for the identification of marketable boletes. Journal of Biotechnology, February 2006, vol. 121, no. 3, p. 318-329.

MOOR, D.; BRODMANN, P.; NICHOLAS, G. and EUGSTER, A. Polymerase chain reaction (PCR) for the detection of king bolete (Boletus edulis) and slippery jack (Suillus luteus) in food samples. European Food Research and Technology, April 2002, vol. 214, no. 4, p. 340-345.

MOREAU, P.A.; PEINTNER, U. and GARDES, M. Phylogeny of the ectomycorrhizal mushroom genus Alnicola (Basidiomycota, Cortinariaceae) based on rDNA sequences with special emphasis on host specificity and morphological characters. Molecular Phylogenetics and Evolution, March 2006, vol. 38, no. 3, p. 794-807.

MULLIS, K.B. and FALOONA, F.A. Specific synthesis of DNA in vitro via a polymerase-catalyzed chain reaction. Methods in Enzymology, 1987, vol. 155, p. 335-350.

OH, S.; KAMDEM, D.P.; KEATHLEY, D.E. and HAN, K.H. Detection and species identification of wood-decaying fungi by hybridization of immobilized sequence-specific oligonucleotide probes with PCR-amplified fungal ribosomal DNA internal transcribed spacers. Holzforschung, 2003, vol. 57, no. 4, p. 346-352.

PEINTNER, U.; IOTTI, M.; KLOTZ, P.; BONUSO, E. and ZAMBONELLI, A. Soil fungal communities in a Castanea sativa (chestnut) forest producing large quantities of Boletus edulis sensu lato (porcini): where is the mycelium of porcini? Environmental Microbiology, April 2007, vol. 9, no. 4, p. 880-889.

SANCHEZ-BALLESTEROS, J.; GONZALEZ, V.; SALAZAR, O.; ACERO, J.; PORTAL, M.A.; JULIAN, M.; RUBIO, V.; BILLS, G.F.; POLISHOOK, J.D.; PLATAS, G.; MOCHALES, S. and PELAEZ, F. Phylogenetic study of Hypoxylon and related genera based on ribosomal ITS sequences. Mycologia, SeptemberOctober 2000, vol. 92, no. 5, p. 964-977.

TANG, W. and LU, X.C. Study of the biological activity and the antitumor activity against sarcoma-180 of Boletus edulis. Journal of Southwest China Normal University (Natural Sciences), August 1999, vol. 24, no. 6, p. 478-481.

TAYLOR, P.W.J. and FORD, R. Diagnostics, genetic diversity and pathogenic variation of ascochyta blight of cool season food and feed legumes. European Journal of Plant Pathology, September 2007, vol. 119, no. 1, p. 127133.
TSAI, S.Y.; TSAI, H.L. and MAU, J.L. Antioxidant properties of Agaricus blazei, Agrocybe cylindracea, and Boletus edulis. Lwt-Food Science and Technology, 2007, vol. 40, no. 8, p. 1392-1402.

URBANELLI, S.; DELLA ROSA, V.; PUNELLI, F.; PORRETTA, D.; REVERBERI, M.; FABBRI, A.A. and FANELLI, C. DNA-fingerprinting (AFLP and RFLP) for genotypic identification in species of the Pleurotus eryngii complex. Applied Microbiology and Biotechnology, March 2007, vol. 74, no. 3, p. 592-600.

VAN HEES, P. A. W.; JONES, D.L.; JENTSCHKE, G. and GODBOLD, D.L. Mobilization of aluminium, iron and silicon by Picea abies and ectomycorrhizas in a forest soil. European Journal of Soil Science, March 2004, vol. 55, no. 1, p. 101-111.

WANG, Y.Q.; ZHOU, K.Y.; XU, L.S.; DONG, T.T.X. and TSIM, K.W.K. Authentication of an animal crude drug, Zaocys, by diagnostic PCR. Biological \& Pharmaceutical Bulletin, May 2000, vol. 23, no. 5, p. 585-588.

WANG, Y.X. and LU, Z.X. Optimization of processing parameters for the mycelial growth and extracellular polysaccharide production by Boletus spp. ACCC 50328. Process Biochemistry, March 2005, vol. 40, no. 3-4, p. 1043-1051.

WEI, J.C. Fungi identification manual (in Chinese). Shanghai Scientific and Technological Press, Shanghai, 1979, p. 780.

WILBURN, R.T.; Vonderheide, A.P.; SOMAN, R.S. and CARUSO, J.A. Speciation of selenium in the mushroom Boletus edulis by high-performance liquid chromatography coupled to inductively coupled plasma-mass spectrometry with a collision cell. Applied Spectroscopy, October 2004, vol. 58, no. 10, p. 1251-1255.

WILSON, A.W.; HOBBIE, E.A. and HIBBETT, D.S. The ectomycorrhizal status of Calostoma cinnabarinum determined using isotopic, molecular, and morphological methods. Canadian Journal of Botany-Revue Canadienne de Botanique, April 2007, vol. 85, no. 4, p. 385-393.

WHITE, T.J.; BRUNS, T.; LEE, S. and TAYLOR, J. Amplification and direct sequencing of fungal ribosomal RNA genes for phylogenetics. In: INNS, M.A.; GELFAND, D.H. SNINSKY, J.J. and WHITE, T.J. eds. PCR Protocols: A Guide to Methods and Applications San Diego, California: Academic Press, 1990, p. 315-322. 